https://doi.org/10.30702/ujcvs/19.35/11(049-051)

УДК 616.13-089 611.132.1 -616.124-007.2-073.7

\title{
Дилатація кореня аорти у пацієнтів з єдиним шлуночком серця після накладання тотального кавопульмонального сполучення
}

\author{
Позняк Ю. В. ${ }^{1}$, Руденко Н. М. ${ }^{1,2}$, Лебідь І. Г. ${ }^{1}$, Байрамов Е. М. ${ }^{1}$, Дзюрман Д. О. ${ }^{1}$ \\ ${ }^{1}$ ДУ «Науково-практичний медичний центр дитячої кардіології та кардіохірургії МОЗ України» (Київ) \\ ${ }^{2}$ Національна академія післядипломної освіти імені П. Л. Шупика (Київ)
}

\begin{abstract}
Накладання тотального кавопульмонального сполучення в модифікації екстракардіального кондуїту - заключний етап гемодинамічної корекції у пацієнтів із функціонально єдиним шлуночком серця. Дилатація кореня і проксимального відділу висхідної аорти в даної когорти хворих має прогресуючий характер.

Мета роботи - проаналізувати віддалені результати спостереження за динамікою дилатації кореня і проксимального відділу аорти у пацієнтів після тотального кавопульмонального сполучення в модифікації екстракардіального кондуїту.

Матеріали та методи. За період з 2005 по 2016 р. 137 пацієнтам із гемодинамічно єдиним шлуночком серця була виконана операція тотального кавопульмонального сполучення, госпітальна летальність склала 2,3\% $(\mathrm{n}=3)$. У групу дослідження включено $116(84,7 \%)$ пацієнтів, у яких проаналізовано динаміку дилатації кореня та висхідної аорти з урахуванням до- та післяопераційних даних.

Результати та обговорення. Статистично достовірно розширення аорти спостерігалося у пацієнтів старшого віку (старше 10 р.) на момент заключного етапу гемодинамічної корекції, відповідно з довшим існуванням в умовах хронічної гіпоксії. Факторами ризику були анатомія єдиного шлуночка серця з транспозиційним ходом великих артерій та/або атрезією легеневої артерії та лівий тип єдиного шлуночка серця.

Висновки. Дилатація кореня та висхідної аорти у пацієнтів із функціонально єдиним шлуночком серця після заключного етапу гемодинамічної корекції має прогресуючий характер. Вік пацієнта, вихідна анатомія вади (хід великих артерій і морфологічний тип шлуночка) є предиктором розширення аорти.
\end{abstract}

Ключові слова: дилатація кореня аорти, тотальне кавопульмональне сполучення, єдиний шлуночок серия.

На заключному етапі гемодинамічної корекції в пацієнтів із функціонально єдиним шлуночком серця запропонована методика тотального кавопульмонального сполучення (ТКПС) в модифікації екстракардіального кондуїту (ЕK), яка набула значного поширення в багатьох кардіохірургічних установах світу. Існує низка ускладнень цього втручання, які в подальшому призводять до прогресування серцевої недостатності та зниження якості життя пацієнта [1].

Незважаючи на те, що накладання ЕК - заключний етап гемодинамічної корекції, у частини пацієнтів проводять повторні хірургічні втручання після ТКПС: пластика/протезування системного атріовентрикулярного клапана, ревізія/заміна ЕК [2, 7].

Дилатація кореня і проксимального відділу висхідної аорти (Ао) - це прогресуюче збільшення в діаметрі одного або декількох розмірів Ао непропорційно соматичному росту дитини або збільшення розмірів у динаміці на 1 см/рік і більше в дорослого пацієнта $[2,3]$.

Розширення кореня та висхідної Ао у пацієнтів 3 ЄШС після накладання ТКПС має прогресуючий характер $[4,5]$. Виражена дилатація кореня Ао призводить до появи аортальної недостатності (AН), що, у свою чергу, є чинником перевантаження об’ємом. Ви- ражена АН достеменно призводить до збільшення кінцево-діастолічних параметрів ЄШС і ремоделювання міокарда, з його подальшою діастолічною та систолічною дисфункцією [7].

Мета роботи - проаналізувати віддалені результати спостереження за динамікою дилатації кореня та проксимального відділу Ао у пацієнтів після ТКПС в модифікації ЕК.

Матеріали і методи. За період із січня 2005 по грудень 2016 р. 137 пацієнтам із гемодинамічно ЄШС ві-

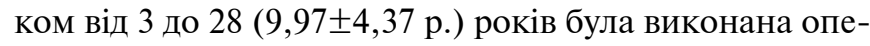
рація ТКПС. Із 137 пацієнтів виписалися зі стаціонару 134 (97,7\%), госпітальна летальність склала 2,3\% (n=3).

Під динамічним спостереженням у віддаленому періоді перебувають 125 хворих $(93,3 \%)$ із терміном спостереження від 6 місяців до 11 років, у середньому $48,2 \pm 18,4$ міс. $(4,0 \pm 1,5$ року). Одночасно з накладанням ТКПС у $7(5,6 \%)$ пацієнтів була виконана операція Damus-Kaye-Stansel (DKS) та у 2 (2,6\%) проводилися кардіохірургічні процедури на корені Ао, які не ввійшли в даний аналіз.

$116(84,7 \%)$ пацієнтів були поділені на дві групи: I група - з дилатацією кореня та висхідного відділу Ао, II група - без дилатації. 
I група: $\mathrm{n}=67$, середній вік $-167 \pm 29$ міс., від 90 до 297 міс., II група: $\mathrm{n}=49$, середній вік $-77 \pm 14$ міс., від 36 до 99 міс.

Основним методом оцінки віддалених результатів хірургічного лікування була трансторакальна ехокардіографія (ЕхоКГ). Динамічне спостереження проводилося кожні 6-12 міс. після накладання ТКПС, при якому виконувалось ЕхоКГ, ЕКГ, вимірювання сатурації крові, тест із 6-хвилинною ходьбою, вимірювання артеріального тиску на обох руках.

За оцінкою стану 116 хворих на час останнього контрольного обстеження, функціональний стан у 82 (70\%) пацієнтів відповідав I класу NYHA, у 31 (28\%) II класу і у 3 (2\%) - III класу.

При вимірюванні артеріального тиску на обох руках діастолічний тиск склав $55 \pm 5$ мм рт. ст.

Основним методом оцінки віддалених результатів операції була комплексна трансторакальна ЕхоКГ. Визначення діаметру кореня та проксимальної частини висхідної Ао проводилось у В-режимі в парастернальній позиції по довгій осі на рівні фіброзного кільця, синусів Вальсальви, синотубулярного з'єднання та проксимальної частини висхідної Ао з подальшим розрахунком z-score для кожного розміру.

Для діагностики максимального та середнього систолічного градієнта на АК використовували п'ятикамерну та супрастернальну позицію в режимі імпульсно-хвильової та постійно-хвильової доплерографії. Ступінь АН оцінювався як мінімальний, невеликий, помірний та виражений. У віддаленому післяопераційному періоді у 4,5\% (n=5) пацієнтів спостерігалася АН помірного ступеня. Виникнення і прогресивне збільшення АН було пов'язано з дилатацією кореня.

У І групі діаметр на рівні фіброзного кільця в середньому склав $25,4 \pm 1,5$ мм, у II групі - 22,6 21,3 мм,

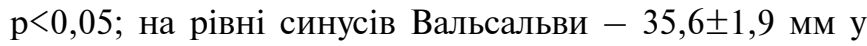
I групі, $30,8 \pm 1,4$ мм у II групі, p $<0,05$; на рівні синотубулярного з'єднання - 30,3 $\pm 1,7$ мм у I групі, $27,7 \pm 1,5$ мм у II групі, $\mathrm{p}<0,05$; на рівні проксимальної частини ви-

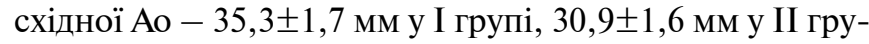
пi, $p<0,05$.

Відповідно значення z-score кореня Ао в середньому склало: на рівні фіброзного кільця - 2,7 $\pm 0,3$ у I гру-

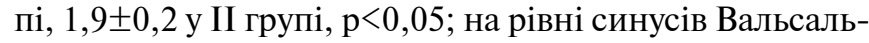

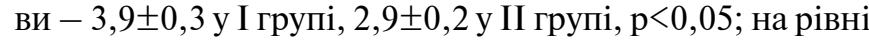

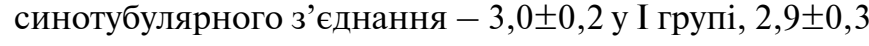
y II групі, $\mathrm{p}<0,05$; на рівні проксимальної частини ви-

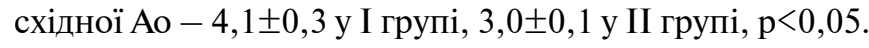

Результати та обговорення. Аналіз даних двох груп вірогідно продемонстрував, що вік пацієнта на момент хірургічного лікування був вищим у пацієнтів I групи порівняно з ІІ групою (167 \pm 29 міс. проти $77 \pm 14$ міс., $\mathrm{p}<0,05)$. Статистично значущий приріст одного з трьох розмірів кореня Ао протягом віддаленого періоду спостереження відмічено у пацієнтів I групи, де превалю- вали діти старшої вікової групи $(\mathrm{p}<0,05)$, що дозволяє припустити, що пацієнти даної вікової категорії (старше 10 р.) знаходяться в зоні ризику розвитку дилатації кореня та висхідної Ао у віддаленому післяопераційному періоді. Відповідно, при вивченні до- та післяопераційних даних у хворих із розширенням кореня та висхідної Ао період між накладанням анастомозу Гленна та ЕК був достовірно довший - 39,5 99,3 міс.

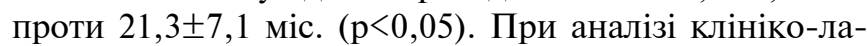
бораторних показників пацієнти I групи мали нижчий рівень сатурації та вищий рівень гемоглобіну крові на момент заключного етапу гемодинамічної корекції. Не виключений вплив хронічної гіпоксії та ціанозу на морфофункціональні зміні на тканинному рівні стінки Ao $[4,5]$.

При дослідженні вихідної анатомії та анатомічних особливостей ходу великих артерій у $71 \%(\mathrm{n}=83)$ пацієнтів I групи виявлено транспозиційний хід $(\mathrm{p}<0,05)$ та/або атрезію легеневої артерії $(\mathrm{p}<0,05)$. При порівнянні анатомічного типу шлуночка в досліджуваних пацієнтів у I групі визначено, що превалював лівий тип ЄШС (атрезія тристулкового клапана, двопритічний лівий шлуночок).

Висновки. Аналіз віддалених результатів хірургічного лікування пацієнтів з СШС після накладання ТКПС показав прогресування дилатації кореня і проксимального відділу висхідної Ао. Статистично достовірно розширення Ао спостерігалося у пацієнтів старшого віку (старше 10 р.) на момент заключного етапу гемодинамічної корекції, відповідно з довшим існуванням в умовах хронічної гіпоксії та поліцитемії. Факторами ризику були анатомія $Є Ш С$ із транспозиційним ходом великих артерій та/або атрезією легеневої артерії та лівий тип ЄШС.

\section{Література}

1. Pundi KN, Johnson JN, Dearani JA, Pundi KN, Li Z, Hinck CA, et al. 40-Year Follow-Up After the Fontan Operation: Long-Term Outcomes of 1,052 Patients. J Am Coll Cardiol. 2015 Oct;66(15):1700-10. https://doi. org/10.1016/j.jacc.2015.07.065

2. Cozijnsen L, Braam RL, Waalewijn RA, Schepens MA, Loeys BL, van Oosterhout MF, et al. What Is New in Dilatation of the Ascending Aorta? Review of Current Literature and Practical Advice for the Cardiologist. Circulation. 2011 Mar;123(8):924-8. https://doi. org/10.1161/CIRCULATIONAHA.110.949131

3. Jain D, Dietz H, Oswald G, Maleszewski JJ, Halushkaa MK. Causes and histopathology of ascending aortic disease in children and young adults. Cardiovasc Pathol. 2011 Jan-Feb;20(1):15-25. https://doi.org/10.1016/j. carpath.2009.09.008

4. Kim YY, Rathod RH, Gauvreau K, Keenan EM, Del Nido P, Geva T. Factors associated with severe aortic dilation in patients with Fontan palliation. Heart. 2017 Feb;103(4):280-6. https://doi.org/10.1136/ heartjnl-2016-309615 
5. Kojima T, Kuwata S, Kurishima C, Iwamoto Y, Saiki H, Ishido $\mathrm{H}$, et al. Aortic root dilatation and aortic stiffness in patients with single ventricular circulation. Circ J. 2014;78:2507-11.

6. Erez E, Tam VK, Galliani C, Lashus A, Doublin NA, Peretti J. Valve-sparing aortic root replacement for patients with a Fontan circulation. J Heart Valve Dis. 2012 Mar;21(2):175-80.
7. Francois K. Aortopathy associated with congenital heart disease: A current literature review. Ann Pediatr Cardiol. 2015 Jan-Apr;8(1):25-36. https://doi.org/10.4103/09742069.149515

8. Egan M, Phillips A, Cook S. Aortic Dissection in the Adult Fontan with Aortic Root Enlargement. Pediatr Cardiol. 2009 May;30(4):562-3. https://doi.org/10.1007/s00246009-9435-0

\title{
Aortic Root Dilatation in Patients with Single Ventricle after Total Cavopulmonary Connection
}

\author{
Poznyak Yu. V. ${ }^{1}$, Rudenko N. M. ${ }^{1,2}$, Lebid I. G. ${ }^{1}$, Bairamov E. M. ${ }^{1}$, Dzurman D. O. ${ }^{1}$ \\ ${ }^{1}$ Ukrainian Children's Cardiac Center (Kyiv) \\ 2 Shupyk National Medical Academy of Postgraduate Education (Kyiv)
}

Extracardiac total cavopulmonary connection (EC TCPC) is the end stage of hemodynamic correction in patients with a functional single ventricle (SV). The dilatation of the aortic root and proximal portion of the ascending aorta (Ao) has a progressive nature in this cohort of patients.

The purpose of this article is to analyse the dynamics of root and proximal Ao dilatation in patients after EC TCPC in the long-term period.

Material and methods. In the period from 2005 to 2016, 137 patients with hemodynamic SV underwent EC TCPC surgery, with hospital mortality being $2.3 \%(n=3)$. Pre- and postoperative data of the aortic root and ascending Ao dilatation have been studied in the group of 116 (84.7\%) patients.

Result and discussion. According to the statistical evidence, Ao dilatation has been observed mainly in older patients (older than 10 years) at the time of hemodynamic correction end stage, with longer exposure to chronic hypoxia, respectively. Transposition of the great arteries and/or pulmonary artery atresia with the left type of SV proved to be major risk factors.

Conclusions. Aortic root and ascending Ao dilatation has a progressive nature in patients with functional SV after the end stage of hemodynamic correction. The patient's age, initial SV anatomy (anatomy of the great arteries and SV morphological type) are predictors of Ao dilatation.

Key words: aortic root dilatation, total cavopulmonary connection, single ventricle. 